\section{Effect of dietary inclusion of different lipid supplements on performance and carcass quality traits of growing beef heifers}

\author{
Attilio Luigi Mordenti, Nico Brogna, \\ Flavia Merendi, Luca Sardi, \\ Marco Tassinari, Ludovica Maria \\ Eugenia Mammi, Elisa Giaretta, \\ Andrea Formigoni \\ Department of Veterinary Medical \\ Sciences, University of Bologna, Ozzano \\ dell'Emilia, Italy
}

\begin{abstract}
The aim of this study was to evaluate the impact of dietary extruded flaxseed and/or rumen-protected lipids on growth performance and carcass quality of growing beef heifers. Sixty-three crossbreed heifers (Charolais X Limousine) were distributed into seven experimental groups, balanced in terms of age and live weight. Diets fed to the groups were isoproteic and differed in both, the dietary lipid source (extruded linseed and/or rumen-protected conjugated linoleic acid) and the supplementation length ( 90 or 180 days before slaughtering), having the same total amount of lipids and vitamin $\mathrm{E}$, during their finishing period. The results obtained in the present study confirm that in low-protein diets, the inclusion of rumen-protected CLA, alone or in combination with flaxseed, did not bring any evident effect on feed intake, performance and carcass quality traits of growing beef heifers.
\end{abstract}

\section{Introduction}

In order to increase nitrogen efficiency and reduce the environmental impact of the Italian beef production chain (Cozzi, 2007), the aim of this study was to evaluate the effects of the use of extruded flaxseed (EF) and/or rumen protected CLA (RPCLA) in low-protein diets on growth and on carcass quality of beef heifers, by identifying the most suitable dietary strategy to improve the effects of linoleic acid (Juarez et al., 2012) and/or of cis-9,trans-11 and trans10,cis-12 CLA isomers. Numerous physiological effects are attributed to conjugated linoleic acid isomers (CLAs). Several researches performed on pigs, dairy cattle and laboratory animals have shown that the supplementation of principal CLA isomers: the cis-9, trans-11 CLA improves animal growth performance and feed efficiency (Pariza et al., 2001), whereas trans-10, cis12 CLA has anti-obesity effects, reducing body fatness (Pariza, 2004). To this aim, animals were fed diets differing in lipid dietary source (EF and/or RPCLA) and length of administration (90 vs. 180 days). The impact of these diets treatments on performance and carcass quality traits of growing beef heifers were evaluated.

\section{Materials and Methods}

The Scientific Ethics Committee on Animal Experimentation of the University of Bologna examined and approved the experimental protocol (n.: 71674-X/6 - All.: 63) used in this study.

\section{Animals, diets and analysis}

Sixty-three crossbreed heifers (Charolais X Limousin) were introduced at the Oasi farm (Rio Saliceto, Reggio Emilia, Italy) with similar characteristics (Age: $11 \pm 1$ months and BW: $380 \pm 7 \mathrm{~kg}$ ). After an adaptation period of 3 weeks, animals were randomly distributed into seven homogenous dietary experimental groups, each consisting of 9 animals ( 3 heifers/pen; 3 pen/treatment); each animal had a space allowance of $4.5 \mathrm{~m}^{2}$.

The diets of the experimental groups differed with respect to the lipid source, provided as supplement, and to the length of administration but, considering their entire experimental period (180 days), the same total amount of lipids was administered to the animals. Dietary groups were as follows: A) control (Basal diet (BD) supplemented with Megalac ${ }^{\circledR}$ and soybean meal (protein 14\% and energy $1762 \mathrm{kcal} / \mathrm{kg}$ ) for 180 days); B) BD plus $250 \mathrm{~g} \mathrm{EF} \mathrm{head}^{-1}$ day- $^{-}$ ${ }^{1}$ and $1 \mathrm{~g}$ Vitamin $\mathrm{E}(\mathrm{VE})$ head $^{-1}$ day $^{-1}$ for 180 days; C) BD (first 90 days) followed by BD supplemented with $500 \mathrm{~g} \mathrm{EF} \mathrm{head}^{-1}$ day $^{-}$ ${ }^{1}$ and $2 \mathrm{~g} \mathrm{VE}$ head $^{-1}$ day $^{-1}$ (last 90 days); D) BD supplemented with $25 \mathrm{~g}^{\mathrm{CLA}}$ head $^{-1}$ day $^{-1}$ and $1 \mathrm{~g} \mathrm{VE}^{\text {head }}{ }^{-1}$ day $^{-1}$ for 180 days; E) BD (first 90 days) followed by BD supplemented with $50 \mathrm{~g} \mathrm{CLA} \mathrm{head}^{-1}$ day $^{-1}$ and 2 $\mathrm{g} \mathrm{VE} \mathrm{head}^{-1}$ day $^{-1}$ (last 90 days); F) BD supplemented with $250 \mathrm{~g} \mathrm{EF}^{\text {head }}{ }^{-1}$ day $^{-1}, 25 \mathrm{~g}$ CLA head ${ }^{-1}$ day $^{-1}$ and $1 \mathrm{~g} \mathrm{VE} \mathrm{head}^{-1}$ day $^{-1}$ for 180 days and $\mathrm{G}) \mathrm{BD}$ supplemented with $250 \mathrm{~g} \mathrm{EF}^{\text {head }}{ }^{-1}$ day $^{-1}$ and $25 \mathrm{~g} \mathrm{CLA} \mathrm{head}^{-1}$ day $^{-1}$ for 180 days. The seven experimental groups received five different diets for the first 90 days of the experimental period (C and $\mathrm{E}$ groups received the A diet) conversely, for the last 90 days of the trial animals received seven different diets. Diets were daily administered with a mixer wagon equipped with a weighing scale; the weight
Correspondence: Attilio Luigi Mordenti, Dipartimento di Scienze Mediche Veterinarie (DIMEVET), Università di Bologna, Via Tolara di sopra 50, 40064 Ozzano Emilia, Bologna, Italy.

Tel.: +39.051.2097381 - Fax: +39.051.2097373.

E-mail: attilio.mordenti@unibo.it

Key words: beef quality; carcass traits; extruded flaxseed; CLA.

Acknowledgements and Funding: Special thanks go to Mr. Benevelli of the CO.NA.ZOO. (Consorzio Nazionale Zootecnico) and Mr. Ronca of the Azienda Agricola OASI (Rio Saliceto - Reggio Emilia) for providing the animals, facilities and zootechnical equipment, as well for their helpful collaboration. The study was conducted in collaboration with the Centro Ricerche Produzioni Animali (CRPA) of Reggio Emilia and funded by the Region of Emilia Romagna (RER) within the project "Healthy Beef Strategie per produrre carne bovina con caratteristiche salutistiche".

Contributions: the authors contributed equally.

Conflict of interest: the authors declare no potential conflict of interest.

Received for publication: 10 July 2018

Revision received: 19 February 2019.

Accepted for publication: 25 February 2019.

This work is licensed under a Creative Commons Attribution-NonCommercial 4.0 International License (CC BY-NC 4.0).

(C) Copyright A.L. Mordenti et al., 2019 Licensee PAGEPress, Italy

Italian Journal of Food Safety 2019; 8:7683

doi:10.4081/ijfs.2019.7683

of the mix uploaded in each pen were recorded daily, the orts that remained in the mangers were weighted by pen weekly and the dry matter intake (DMI) of each pen was recorded weekly, as the difference between the daily amount provided and the remainder. Water and total mixed ration (TMR) were administered ad libitum. TMR and supplements samples were taken on a monthly basis $(n=6)$ and then transported to the DIMEVET laboratories for chemical analysis, the proximate analysis are reported in Tables 1 and 2. Table 2 shows also the percentage fatty acid composition of the experimental supplements lipid fractions, added directly to TMR. According to the experimental design, $\mathrm{C}$ diet provided a double intake of $\alpha$-linolenic acid than B, E, F, D and $\mathrm{G}$ diets. The supplementation in the control group, included with wheat bran middlings, soybean meal, Megalac ${ }^{\circledR}$ and beet pulp, ensured the same theoretical lipid 
amount as oleic acid content. The technical specifications of CLAs supplement (LUTACLA $^{\circledR} 20$ ) guarantee a minimum of $56 \%$ of conjugated linoleic acid methyl ester $(28 \%$ cis-9, trans-11 CLA and 28\% trans-10, cis12 CLA). A triglycerides mixture (mainly stearic acid) was used as coating protection from ruminal hydrogenation and guarantee a good stability of the product.

All analyses on TMR and supplements were performed according to AOAC (2000), with the exception of fiber analysis (Van Soest, 1991). The fatty acid profile of each supplement was determined according to Folch et al. (1957) and Stoffel et al. (1959).

\section{Growth and slaughtering parameters}

Heifers were individually weighed on the same day at the beginning of the trial, after 90 days (mid trial) and after 180 days (end of the trial), in order to calculate average daily gain (ADG) and feed conversion rate (FCR) and feed efficiency (FE) (Table 3 ). When animals reached an average body weight of $675 \mathrm{~kg}$, they were transported to a slaughtering facility (Unipeg, Reggio Emilia) and slaughtered on the same day. Hot carcass weights were registered. Carcasses were refrigerated for $24 \mathrm{~h}$, and then re-weighted to record cold carcass weights; these data were used to calculate dressing-out percentages. Carcass traits were classified and recorded according to the EUROP classification grid (European Commission, 1991). Thus conformation was linearly scored in 18 classes from $\mathrm{S}+$ (all muscle profiles extremely convex; superior muscle development) to P- (all muscle profiles concave to very concave; poor muscle development) considering the profiles of shoulders, loins, rump, thighs, and buttocks $(\mathrm{S}+=6.33 ; \mathrm{P}-=0.66)$, and fat covering was linearly scored considering the presence and the thickness of subcutaneous fat depots at specific points of the body $(1=$ very lean; $5=$ very fat $)$. Twentyfour hours after slaughtering, a three-rib sample $\left(20 \mathrm{~cm}\right.$ of thickness from the $7^{\text {th }}-9^{\text {th }}$ thoracic vertebrae) of Longissimus thoracis et lumborum muscle (LT), was taken from the half right carcass of each of the 63 heifers. Each sample was deboned and the first and last slices were cut and discarded. After $30 \mathrm{~min}$ of exposure to air, two $\mathrm{pH}$ determinations were carried out in the LT muscle using an Orion portable $\mathrm{pH}$ meter (model 250A, Orion Research, Boston, MA), and color ( $\left.L^{*}, a^{*}, b^{*}\right)$ was measured using a Minolta Chromameter CR-200 (Illuminant D65, aperture size $8 \mathrm{~mm}$; Minolta Camera, Osaka, Japan) and used to calculate Hue $\left(\mathrm{h}=\tan -1 \mathrm{~b} * \mathrm{a}^{*}\right)$ and Chroma $\left(C^{*}=\sqrt{ }\left(a^{*}\right)^{2}+\left(b^{*}\right)^{2}\right)$ values.

Table 1. Ingredients (kg/head per day) and chemical composition (\% DM) of the TMR administered daily to heifers.

\begin{tabular}{|c|c|c|c|}
\hline Items & & Fatty acid composition & $\mathrm{g} / \mathrm{kg}$ \\
\hline Samples (n) & 6 & & \\
\hline DM (\%) & 42.8 & & \\
\hline Ether extract & 2.6 & & \\
\hline Protein & 12.1 & C16:0 & 2.7 \\
\hline NPN & 3.3 & C18:0 & 0.6 \\
\hline Ash & 6.7 & $\mathrm{C} 18: \ln 9$ & 2.6 \\
\hline NDF & 37.3 & $\mathrm{C} 18: 2 \mathrm{n} 6$ & 4.0 \\
\hline $\mathrm{ADF}$ & 22.0 & C18:3n3 & 0.5 \\
\hline ADL & 2.5 & CLAs & - \\
\hline $\mathrm{Ca}$ & 0.8 & & \\
\hline$\underline{P}$ & 0.3 & & \\
\hline
\end{tabular}

$\mathrm{DM}=$ dry matter; $\mathrm{NPN}=$ non proteic nitrogen; $\mathrm{NDF}=$ neutral detergent fiber; $\mathrm{ADF}=$ acid detergent fiber; $\mathrm{ADL}=$ acid detergent lignin. Maize silage 8; Beet pulp silage 5; Corn meal 2.5; Straw 0.8; Concentrate 6.Concentrate included toasted soybean meal, sunflower meal, maize gluten, soybean meal, rice bran, cane sugar molasses, dicalcium phosphate, sodium bicarbonate, sodium chloride and dry yeast.

Table 2. Chemical composition of the experimental supplements administered to heifers.

\begin{tabular}{|c|c|c|c|c|c|c|c|}
\hline \multirow[t]{2}{*}{ Item } & \multicolumn{6}{|c|}{ Experimental supplements } & \multirow[b]{2}{*}{ G } \\
\hline & A & B & C & D & $\mathbf{E}$ & $\mathbf{F}$ & \\
\hline Samples (n.) & 6 & 6 & 3 & 6 & 3 & 6 & 6 \\
\hline DM (\%) & 89.9 & 91.1 & 93.4 & 89.2 & 90.6 & 90.4 & 90.6 \\
\hline Protein (\%) & 23.1 & 24.0 & 22.2 & 26.0 & 25.8 & 23.1 & 22.2 \\
\hline Ether extract (\%) & 20.9 & 21.7 & 22.2 & 21.2 & 22.7 & 21.8 & 22.0 \\
\hline \multicolumn{8}{|c|}{ Fatty acid composition (g/kg) } \\
\hline $\mathrm{C} 16: 0$ & 16.6 & 13.9 & 10.6 & 25.9 & 35.3 & 18.6 & 18.1 \\
\hline $\mathrm{C} 18: 0$ & 2.5 & 2.8 & 3.8 & 19.9 & 28.3 & 13.7 & 12.4 \\
\hline $\mathrm{C} 18: 1$ cis 9 & 107.1 & 84.7 & 61.5 & 75.7 & 55.9 & 66.7 & 65.8 \\
\hline C18:2n-6 & 49.7 & 43.1 & 36.0 & 41.2 & 31.0 & 31.4 & 32.2 \\
\hline C18:3n-3 & 4.0 & 36.9 & 69.9 & 6.4 & 11.2 & 46.3 & 49.3 \\
\hline CLAs & - & - & - & 13.1 & 20.9 & 7.2 & 6.7 \\
\hline
\end{tabular}

$\mathrm{DM}=\mathrm{dry}$ matter; CLAs=conjugated linoleic acid isomers. Groups: A) control (Basal diet supplemented with Megalac ${ }^{\circledR}$ and soybean meal (protein $14 \%$ and energy $1762 \mathrm{kcal} / \mathrm{kg}$ ) for $180 \mathrm{days)}$ ); B) Basal diet plus $250 \mathrm{~g}$ EF

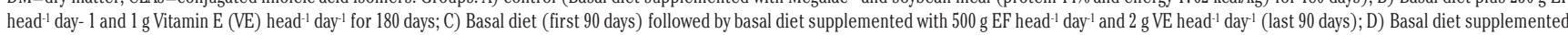

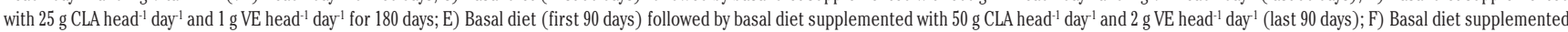

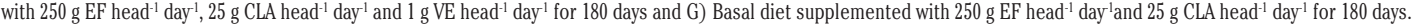




\section{Results}

Regarding CLAs content shown in Table 2, D and E diets covered the expected levels, while $\mathrm{F}$ and $\mathrm{G}$ diets had lower CLAs levels than theoretical ones.

Table 3 reports the ADG, DMI, FCR and FE of the entire period: no statistically significant differences were observed. Moreover, no differences emerged in carcass traits. As regards the ADG of the first and the second parts of the trial, we have observed some statistical differences $(\mathrm{P} \leq 0.05)$ between the $\mathrm{G}$ group and the control one (in the first period, 0-90 d), and between the $\mathrm{G}$ group and $\mathrm{E}$ group (in the second period, 90-180 d); these differences become not significant considering the whole experimental period.

As reported in Table 4, considering dressing out and EUROP classification data no differences were observed between groups. Carcass weight averaged $400.6 \mathrm{~kg}$ and dressing out percentage averaged 59.7 $\%$; as regards slaughtering parameters, conformation averaged 3.96 and fat covering averaged 2.52. Significant differences $(\mathrm{P} \leq 0.05)$ were detected in the $\mathrm{pH}$ values measured at $24 \mathrm{~h}$ after slaughtering. In fact, the $\mathrm{pH}$ values of group $\mathrm{A}, \mathrm{C}$ and $\mathrm{E}$ were significantly lower than others dietary groups. Regarding the color measurements performed in the fresh meat, particularly for $\mathrm{L}$ value, Hue and Chroma data no statistical differences were observed among the different treatments.

\section{Discussion}

As expected from literature (Schiavon et al., 2010; Mordenti et al., 2005) the use of EF and/or CLA did not influenced DMI during the sperimentation. The differences observed between groups in ADG (0-90 d) and ADG (90-180 d) have been irrelevant, due to the heifers' compensatory growth, in fact no differences have been observed in ADG of the entire trial. Concerning heifers' growth, slaughter weights and dressing out, our data were similar with our previous trials (Mordenti et al., 2005). As regards physiological effects attributed to both major CLAs, they were not particularly evident in this trial. This fact is probably due both to the low protein density of the diet and to the use of a typical lean crossbreed (Charolais $\mathrm{X}$ Limousin) with a low-fat deposit in the body. The $\mathrm{pH}$ data, at $24 \mathrm{~h}$ from slaughter, are similar to those found by Juarez et al. (2012); the drop of meat $\mathrm{pH}$ value is a desirable factor to start protein denaturation and cathepsins activation (Keeton et al., 2008).

Table 3. Animal parameters of heifers at the end of the trial.

\begin{tabular}{|c|c|c|c|c|c|c|c|c|c|}
\hline \multirow[t]{2}{*}{ Item } & \multirow[b]{2}{*}{ A } & \multicolumn{4}{|c|}{ Experimental groups } & \multirow[b]{2}{*}{ F } & \multirow[b]{2}{*}{ G } & \multirow[t]{2}{*}{ SEM } & \multirow[t]{2}{*}{$\mathbf{P}$} \\
\hline & & B & C & D & E & & & & \\
\hline Weight at 0 day (kg) & $390^{\mathrm{A}}$ & $377^{\mathrm{B}}$ & $387^{\mathrm{A}}$ & $375^{\mathrm{B}}$ & $372 B$ & $374 \mathrm{~B}$ & $378 \mathrm{~B}$ & 3.54 & $\leq 0.01$ \\
\hline Weight at 90 days (kg) & 522 & 534 & 534 & 537 & 507 & 515 & 553 & 5,40 & n.s. \\
\hline Weight at 180 days (kg) & 667 & 681 & 686 & 676 & 661 & 666 & 686 & 4.39 & ns \\
\hline DMI 0-1801 (kg DM/d) & 10.22 & 10.32 & 9.94 & 10.60 & 9.95 & 10.45 & 10.16 & 0.15 & ns \\
\hline ADG 0-901 (kg/d) & $1.45^{\mathrm{b}}$ & $1.72^{\mathrm{ab}}$ & $1.62^{\mathrm{ab}}$ & $1.78^{\mathrm{ab}}$ & $1.48^{\mathrm{ab}}$ & $1.55^{\mathrm{ab}}$ & $1.84^{\mathrm{a}}$ & 0.04 & $\leq 0.05$ \\
\hline ADG 90-1801 (kg/d) & $1.60^{\mathrm{ab}}$ & $1.64^{\mathrm{ab}}$ & $1.68^{\mathrm{ab}}$ & $1.54^{\mathrm{ab}}$ & $1.70^{\mathrm{a}}$ & $1.68^{\mathrm{ab}}$ & $1.41^{\mathrm{b}}$ & 0.03 & $\leq 0.05$ \\
\hline ADG 0-1801 (kg/d) & 1.54 & 1.69 & 1.66 & 1.67 & 1.60 & 1.62 & 1.62 & 0.02 & ns \\
\hline FCR 0-1801 & 6.66 & 6.12 & 6.06 & 6.37 & 6.25 & 6.45 & 6.33 & 0.07 & ns \\
\hline FE 0-180 & 0.15 & 0.16 & 0.17 & 0.16 & 0.16 & 0.16 & 0.16 & 0.01 & ns \\
\hline
\end{tabular}

Values in the same row with different superscripts are different ( $\mathrm{a}$ and $\mathrm{b}, \mathrm{P} \leq 0.05 ; \mathrm{A}$ and $\mathrm{B} \mathrm{P} \leq 0.01$ ). $\mathrm{SEM}=$ standard error mean; DMI=dry matter intake; $\mathrm{ADG}=$ average daily gain; $\mathrm{FCR}=$ feed conversion rate; Groups: $\mathrm{A}$ ) control (Basal diet supplemented with Megalac $®$ and soybean meal (protein $14 \%$ and energy $1762 \mathrm{kcal} / \mathrm{kg}$ ) for 180 days); B) Basal diet plus $250 \mathrm{~g}^{\mathrm{E}}$, head ${ }^{-1}$ day- 1 and $1 \mathrm{~g}$ Vitamin E (VE) head ${ }^{-1}$ day ${ }^{-1}$ for 180 days; C)

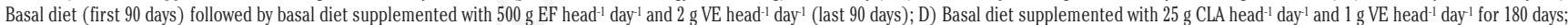

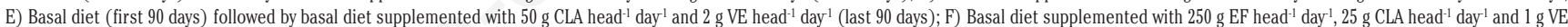
head $^{-1}$ day $^{-1}$ for 180 days and G) Basal diet supplemented with $250 \mathrm{~g} \mathrm{EF} \mathrm{head}^{-1}$ day-1and $25 \mathrm{~g}^{-1}$ CA head- ${ }^{-1}$ day ${ }^{-1}$ for 180 days. IInitial weight was used as a covariate for statistical analysis.

Table 4. Slaughtering parameters and carcass traits of heifers at the end of the trial.

\begin{tabular}{|c|c|c|c|c|c|c|c|c|c|}
\hline Item & & & & rental & & & & SEM & P \\
\hline & $\mathbf{A}$ & B & C & D & $\mathbf{E}$ & $\mathbf{F}$ & $\mathbf{G}$ & & \\
\hline Hot carcass weight (kg) & 401 & 406 & 403 & 404 & 396 & 385 & 409 & 3.53 & $\mathrm{~ns}$ \\
\hline Cold carcass weight (kg) & 393 & 398 & 395 & 396 & 388 & 377 & 401 & 3.46 & ns \\
\hline Dressing out (\%) & 59.9 & 59.6 & 58.4 & 59.8 & 59.7 & 59.7 & 60.1 & 0.30 & $\mathrm{~ns}$ \\
\hline $\begin{array}{l}\text { EUROP } \\
\text { Conformation } \\
\text { Fat covering } \\
\text { pH at } 24 \mathrm{~h}\end{array}$ & $\begin{array}{l}4.00 \\
2.70 \\
5.53^{c}\end{array}$ & $\begin{array}{l}4.00 \\
2.78 \\
5.67^{\mathrm{a}}\end{array}$ & $\begin{array}{l}3.70 \\
2.40 \\
5.47^{\mathrm{c}}\end{array}$ & $\begin{array}{l}4.00 \\
2.33 \\
5.58^{\mathrm{b}}\end{array}$ & $\begin{array}{l}3.90 \\
2.30 \\
5.50^{\mathrm{c}}\end{array}$ & $\begin{array}{l}4.00 \\
2.67 \\
5.69^{\mathrm{a}}\end{array}$ & $\begin{array}{l}4.13 \\
2.50 \\
5.63^{\mathrm{a}}\end{array}$ & $\begin{array}{l}0.13 \\
0.20 \\
0.01\end{array}$ & $\begin{array}{c}\text { ns } \\
\text { ns } \\
\leq 0.05\end{array}$ \\
\hline $\begin{array}{l}\text { Color at } 24 \mathrm{~h} \\
\text { L value } \\
\mathrm{a}^{*} \text { value } \\
\mathrm{b}^{*} \text { value } \\
\text { Hue } \\
\text { Chroma } \\
\end{array}$ & $\begin{array}{l}41.1 \\
27.4 \\
14.7 \\
0.49 \\
31.1 \\
\end{array}$ & $\begin{array}{l}41.8 \\
28.7 \\
15.9 \\
0.51 \\
32.8 \\
\end{array}$ & $\begin{array}{l}41.5 \\
29.4 \\
16.1 \\
0.50 \\
33.6 \\
\end{array}$ & $\begin{array}{l}43.5 \\
28.5 \\
15.8 \\
0.51 \\
32.6 \\
\end{array}$ & $\begin{array}{l}42.8 \\
27.1 \\
15.4 \\
0.52 \\
31.2 \\
\end{array}$ & $\begin{array}{l}42.7 \\
30.6 \\
16.8 \\
0.50 \\
34.9 \\
\end{array}$ & $\begin{array}{l}43.1 \\
27.7 \\
15.7 \\
0.52 \\
31.9 \\
\end{array}$ & $\begin{array}{l}0.30 \\
0.43 \\
0.22 \\
0.01 \\
1.73 \\
\end{array}$ & $\begin{array}{l}\text { ns } \\
\text { ns } \\
\text { ns } \\
\text { ns } \\
\text { ns }\end{array}$ \\
\hline
\end{tabular}

Values in the same row with different superscripts are different ( $\mathrm{a}$ and $\mathrm{b}, \mathrm{P} \leq 0.05 ; \mathrm{A}$ and $\mathrm{B} \mathrm{P} \leq 0.01$ ). $\mathrm{SEM}=$ standard error mean; $\mathrm{DM}=\mathrm{dry}$ matter; $\mathrm{EF}=$ extruded flaxseed; CLA=rumen-protected CLA; VE=vitamin $\mathrm{E}$. Groups: A) control (Basal diet supplemented with Megalac ${ }^{\circledR}$ and soybean meal (protein $14 \%$ and energy $1762 \mathrm{kcal} / \mathrm{kg}$ ) for 180 days); B) Basal diet plus $250 \mathrm{~g}$ EF head ${ }^{-1}$ day- 1 and $1 \mathrm{~g}$ Vitamin $\mathrm{E}$ (VE) head ${ }^{-1}$ day ${ }^{-1}$ for 180 days; C) Basal diet (first 90 days) followed by basal diet supplemented with $500 \mathrm{~g} \mathrm{EF} \mathrm{head}^{-1}$ day $^{1}$ and $2 \mathrm{~g} \mathrm{VE}$ head $^{-1}$ day $^{1}$ (last 90 days); D) Basal diet supplemented with $25 \mathrm{~g} \mathrm{CLA} \mathrm{head}^{-1}$ day ${ }^{-1}$ and $1 \mathrm{~g} \mathrm{VE} \mathrm{head}^{-1}$ day $^{-1}$ for

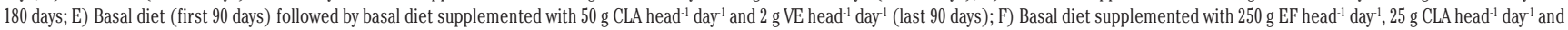
$1 \mathrm{~g} \mathrm{VE}$ head $^{-1}$ day $^{-1}$ for 180 days and G) Basal diet supplemented with $250 \mathrm{~g} \mathrm{EF} \mathrm{head}^{-1}$ day $^{1}$ and $25 \mathrm{~g} \mathrm{CLA} \mathrm{head}^{-1}$ day $^{-1}$ for 180 days. 
The cause of this statistical difference found in $\mathrm{pH}$ values is extremely difficult to evaluate because more than one factor plays an important role, such as: carcass fatness, animal age, breed, length of fasting period, transport time spent to the slaughtering facility, and then that waiting to the abattoir (Sgoifo Rossi et al., 2009). In any case, this parameter did not impact the meat physical properties, such as instrumental color (at 24 $\mathrm{h}$ after slaughtering) and/or tenderness on fresh or cooked meat (obtained under conditions of cooking loss determination) (Mordenti et al., 2018). Moreover, after meat ageing (Mordenti et al., 2018), no significant $\mathrm{pH}$ differences were observed among treatments.

\section{Conclusions}

The results obtained in the present study confirm that in low-protein diets, the inclusion of rumen-protected CLA, alone or in combination with EF, did not highlight any evident effect on performance and carcass quality traits of growing beef heifers. Considering the length of administration (90 or 180 days), the inclusion of rumenprotected CLA and/or in combination with flaxseed, has not led any additional further effect.

\section{References}

AOAC (Association of Official Analytical
Chemists), 2000. Official methods of analysis. 17th edition AOAC, Gaithersburg, MD, USA.

Cozzi G, 2007. Present situation and future challenges of beef cattle production in Italy and the role of the research. Ital J Anim Sci 6:389-96.

European Commission, 1991. Community Scale for the Classification of Carcasses of Adult Bovine Animals. Official Publications of the European Communities, Nos. 1208/81, 2939/81 and 1026/91, Luxembourg.

Folch J, Lees M, Sloane-Stanley GH, 1957. A simple method for the isolation and purification of total lipids from animal tissues. J Biol Chem 226:497-509.

Juarez M, Dugan MER, Aldai N, Basarab JA, Baron VS, McAllister TA, Aalhus JL, 2012. Beef quality attributes as affected by increasing the intramuscular levels of vitamin E and omega-3 fatty acids. Meat Sci 90:764-9.

Keeton JT, Benli H, Claflin, AAE 2008. Carbohydrates. In: Nollet LML, Toldrà $F$ Handbook of muscle food analysis. Ed CRC Press, London, UK.

Mordenti AL, Gatta PP, Lambertini L, Tassinari M, 2005. Effect of dietary supplementation with LCPUFA of vegetable origin in lipid content of muscular and subcutaneous tissues in heifers. Progr Nutr 7:201-10.

Mordenti AL, Merendi F, Vecchia P, Panciroli A, Tassinari M, Brogna N, 2013. Effect of different lipid supplements on steer performance, meat quality and fatty acid composition of
Longissimus dorsi muscle. Proceedings of ASPA $20^{\text {th }}$ Congress Bologna, June 11-13. Ital J Anim Sci 12:C-036.

Mordenti AL, Brogna N, Merendi F, Formigoni A, Sardi L, Cardenia V, Rodriguez-Estrada MT, 2019. Effect of dietary inclusion of different lipid supplements on quality and oxidative susceptibility of beef meat. Ital J Anim Sci 18:105-10.

Pariza MW, Park Y, Cook ME, 2001. The biologically active isomers of conjugated linoleic acid. Prog Lipid Res 40:28398.

Pariza MW, 2004. Perspective on the safety and effectiveness of conjugated linoleic acid. Am J Clin Nutr 79:1132S-6S.

Schiavon S, Tagliapietra F, Dal Maso M, Bailoni L, Bittante G, 2010. Effects of low-protein diets and rumen-protected conjugated linoleic acid on production and carcass traits of growing doublemuscled Piemontese bulls. J Anim Sci 88:3372-83.

Sgoifo Rossi CA, Dell'Orto V, Santini S, 2009. Qualità della carne bovina determinante la gestione. Informatore Zootecnico 19:18-23.

Stoffel W, Chu F, Ahrens Jr. EH, 1959. Analysis of Long-Chain Fatty Acids by Gas-Liquid Chromatography. Anal Chem 31:307-8.

Van Soest PJ, Robertson JB, Lewis BA, 1991. Methods for dietary fiber neutral detergent fiber, and non-starch polysaccharides in relation to animal nutrition. J Dairy Sci 74:583-97. 